Biology-Botany

\title{
Brassicaceae Burnett in the municipality of Santa Maria, Rio Grande do Sul, Brazil
}

\author{
Brassicaceae Burnett no município de Santa Maria, Rio Grande do Sul, \\ Brasil
}

Isabel Costa Borges' ${ }^{\mathbb{D}}$, Liliana Essi' ${ }^{(\mathbb{D})}$

'Universidade Federal de Santa Maria, Santa Maria, RS, Brazil

\begin{abstract}
Brassicaceae (Cruciferae) includes invasive species as well as widely cultivated horticultural species. In Santa Maria, Cruciferae species usually occur in environments that have undergone urbanization such as sidewalks, roadsides, walls, near energy poles, etc. The last listing of species of this family in the area was performed by Romeu Beltrão in 1962 and supplemented in 1965. The objective of the current study was to update the number of records of Brassicaceae species that occur in the municipality of Santa Maria, RS, as well as to provide keys for the identification for native and naturalized genera and species. Bibliographic surveys, field collections, herbarium material analysis and data from databases of speciesLink and Flora of Brazil 2020 were carried out, as well as complementary collections from August 2018 to April 2019. The species found were photographed and identified based on the existing literature. Identification keys for genera and species, as well as illustrations, were prepared. All genera had only one representative species in Santa Maria with the exception of Lepidium, which presented three species. There was an addition of three species and one genus in relation to the last survey carried out.
\end{abstract}

Keywords: Cruciferae; Floristic; Taxonomy; Romeu Beltrão; Lepidium

\section{RESUMO}

Brassicaceae (Cruciferae) possui espécies invasoras e espécies amplamente cultivadas como hortícolas. Em Santa Maria, ocorrem em ambientes que sofreram urbanização como calçadas, beira de rodovias, muros, próximas a postes de energia, entre outros locais. O último levantamento de espécies dessa família no município foi realizado por Romeu Beltrão em 1962 e complementado em 1965. Com base nisso, o objetivo desse estudo foi o de atualizar os registros de Brassicaceae que ocorrem no município de Santa Maria, RS, bem como fornecer chaves para identificação para gêneros e espécies nativos e naturalizados. Foram realizados levantamentos bibliográficos, coletas de campo, análises de materiais de herbário e banco de dados dos sítios speciesLink e Flora do Brasil 2020, bem como coletas complementares de agosto de 2018 a abril de 2019. As espécies foram fotografadas e identificadas com 
base na literatura especializada. Foram elaboradas chaves de identificação para gêneros e espécies, bem como ilustrações. Ao todo, foram registradas 10 espécies nativas ou naturalizadas pertencentes a oito gêneros. Todos os gêneros apresentaram apenas uma espécie representante em Santa Maria com exceção de Lepidium que apresentou três espécies. Houve um acréscimo de três espécies e um gênero em relação ao último levantamento realizado.

Palavras-chave: Cruciferae; Florística; Taxonomia; Romeu Beltrão; Lepidium

\section{INTRODUCTION}

The municipality of Santa Maria is located in the central region of the state of Rio Grande do Sul, and comprises about 1,781,566 km² (IBGE, 2019) with a large proportion of native forest that has undergone anthropic alteration due to agriculture and urban development, disturbing the natural structure (LONGHI et al., 2000). Many species of Brassicaceae Burnett are found in anthropic environments such as these, and can be found on the edges of railroad tracks, in sidewalks, near power posts, in cracks on walls, among other urbanized and disturbed locations.

Brassicaceae Burnett, or Cruciferae, is a family, which comprises about 3,973 species, 52 tribes and 341 genera $(\mathrm{KOCH}$ et al., 2018). It is represented by a considerable number of horticultural (cabbage, broccoli, arugula, etc.), oilseed (canola) and forage species (oildseed radish) and has model organisms (thale cress) in plant studies (LYZAK; KOCH, 2010). It also has species that are considered invasive (birdsrape mustard) in regions outside its native range (PRINA, 1995), as well as unconventional food plants (UFP), like oildseed radish.

Members of the family are annual or perennial herbs, occasionally shrubs or trees. They have flowers of variable color and can be white, yellow, red or violet. Flowers are tetramers with four petals and four sepals that form a cross, except for some species where the petals are absent, such as Lepidium ruderale L. (BONA, 2014), a non-native ruderal species from Rio Grande do Sul. Members of this family can usually be easily distinguished by the presence in most species of six stamens set in two whorls, 4 of which are larger and 2 are smaller. They have simple leaves, basal leaves that are often rosular, stem leaves alternate, all alternating, and rarely opposite, usually pinatissectal, without stipules. They have variable nectaries in 
number and disposition, sometimes assembled into a ring around the stamens. The ovary is falsely bilocular and the placentation is parietal. The fruit may be a variable, dehiscent or indehiscent syllique or silicle. Its seeds contain a fleshy embryo rich in oils (JUDD et al., 2008; SOUZA; LORENZI, 2019).

The family has a cosmopolitan distribution (SOUZA; LORENZI, 2019), being found mainly in temperate and dry climate regions of the Northern and Southern Hemispheres (SCALON; SOUZA, 2002). In the tropics, the distribution of Brassicaceae is limited to mountainous and alpine regions. The most important centers of diversification are in the Irano-Turanian region and the Mediterranean region (LYZAK; KOCH, 2010). In Brazil, a total of 12 genera and 26 species are found, most abundant in the South and Southeast of the country (Flora do Brasil 2020 em construção, 2020).

For the municipality of Santa Maria, RS, the only list of species available for the family was elaborated by Professor Romeu Beltrão in 1962 and supplemented in 1965 (BELTRÃO, 1962, 1965). The present work aims to update the number of native and naturalized Brassicaceae species and genera that occur in Santa Maria, as well as to provide keys for the identification, illustrations and images of the species.

\section{MATERIALS AND METHODS}

\subsection{Study Site}

Santa Maria is located in the central region of Rio Grande do Sul, between the parallels $29^{\circ} 43^{\prime} 57$ "S and $29^{\circ} 55^{\prime} 30^{\prime \prime} \mathrm{S}$ and the meridians $53^{\circ} 42^{\prime} 13^{\prime \prime} \mathrm{W}$ and $53^{\circ} 48^{\prime} 02^{\prime \prime} \mathrm{W}$, with a territory of approximately 178,000 hectares. According to Dal'Asta (2009), the municipality is in the temperate climatic range and has the characteristics of Subtropical climate type Cfa. According to climate classification of Köppen, therefore, the municipality has a humid subtropical climate. As a result, 
the study area is marked by the predominance of intense summers and welldistributed rains throughout the year, whose thermal averages vary between $17^{\circ} \mathrm{C}$ and $19^{\circ} \mathrm{C}$ (PEREIRA et al. 1989). The average temperature of the hottest month, January, is $24.8{ }^{\circ} \mathrm{C}$ and the coldest month, July, is $14.1^{\circ} \mathrm{C}$. The average annual precipitation of the study area is $1,769 \mathrm{~mm} /$ year (LONGHI et al. 2000).

\subsection{Species List and Descriptions}

An initial survey of Brassicaceae records was carried out at the SMDB herbarium of Botanical Garden of Federal University of Santa Maria, on the speciesLink network (http://splink.cria.org.br/), and Flora do Brasil 2020 (http:// http://floradobrasil.jbrj.gov.br/), as well as complementary field collections. The fieldwork was carried from August 2018 to April 2019. The collected material was identified and then herborized. Identifications and descriptions of the species were based on the works of Boelcke (1967) and Scalon and Souza (2002). The identified materials were deposited in the SMDB herbarium. The species found were tabulated with scientific name, origin, vernacular name (when available), and voucher. All acronyms follow Thiers (continuously updated).

\subsection{Preparation of Images}

The species were photographed with a Fujifilm SL300 semi-professional field camera with a black background and then edited digitally for lighting adjustments. The illustrations were made on parchment paper with pen ink, from reduced copies of the exsiccates, observation of photos and plants, and used a drawing tube coupled with stereoscopic microscope brand Leica model M80 for illustrations of flowers and fruits. 


\section{RESULTS AND DISCUSSION}

Ten taxa of Brassicaceae were found in Santa Maria (Table 1), belonging to eight genera: Brassica L., Capsella Medik., Cardamine L., Coronopus Zinn, Lepidium L., Raphanus L., Rapistrum Crantz and Sisymbrium L. Each genus had one species in Santa Maria with the exception of Lepidium, which had three species. The genus Lepidium is one of the largest genera in Brassicaceae, with 250 species (ALSHEHBAZ, 2012).

Table 1 - Brassicaceae species found in Santa Maria municipality, State of Rio Grande do Sul, Brazil, with origin, vernacular names, and vouchers

\begin{tabular}{|c|c|c|c|}
\hline Species & $\begin{array}{c}\text { Native or } \\
\text { Naturalized }\end{array}$ & $\begin{array}{c}\text { Vernacular name } \\
\text { (Portuguese; English) }\end{array}$ & Voucher \\
\hline Brassica rapa L. & $\begin{array}{c}\text { Naturalized, } \\
\text { originated in Europe } \\
\text { and introduced as a } \\
\text { forage. }\end{array}$ & Nabo silvestre; Field Mustard & $\begin{array}{c}\text { I.C. Borges 3, SMDB } \\
18280\end{array}$ \\
\hline $\begin{array}{l}\text { Capsella bursa-pastoris (L.) } \\
\text { Medik. }\end{array}$ & $\begin{array}{l}\text { Naturalized, } \\
\text { originated in Europe } \\
\text { and introduced } \\
\text { accidentally. }\end{array}$ & $\begin{array}{l}\text { Bolsa-de-Pastor; Shepherd's } \\
\text { Purse }\end{array}$ & $\begin{array}{c}\text { I.C. Borges 2, SMDB } \\
18279\end{array}$ \\
\hline $\begin{array}{l}\text { Cardamine bonariensis } \\
\text { Pers. }\end{array}$ & $\begin{array}{c}\text { Naturalized, } \\
\text { originated in Central } \\
\text { America and } \\
\text { introduced } \\
\text { accidentally. }\end{array}$ & Agriãozinho & $\begin{array}{c}\text { I.C. Borges 70, SMDB } \\
18463\end{array}$ \\
\hline $\begin{array}{l}\text { Coronopus didymus (L.) } \\
\text { Sm. }\end{array}$ & Naturalized & Mestruz; Swinecress & $\begin{array}{c}\text { I.C. Borges 4, SMDB } \\
18281\end{array}$ \\
\hline Lepidium aletes J.F.Macbr. & Native & Mastruço; Peppergrass & $\begin{array}{c}\text { I.C. Borges 50, SMDB } \\
18461\end{array}$ \\
\hline Lepidium bonariense L. & Native & $\begin{array}{c}\text { Agrião-selvagem; Argentine } \\
\text { Pepperweed }\end{array}$ & $\begin{array}{c}\text { G. Rau s.n., SMDB } \\
305\end{array}$ \\
\hline
\end{tabular}


Table 1 - Conclusion

\begin{tabular}{|c|c|c|c|}
\hline Species & $\begin{array}{l}\text { Native or } \\
\text { Naturalized }\end{array}$ & $\begin{array}{c}\text { Vernacular name } \\
\text { (Portuguese; English) }\end{array}$ & Voucher \\
\hline Lepidium virginicum L. & $\begin{array}{l}\text { Naturalized, } \\
\text { originated in North } \\
\text { America and } \\
\text { introduced } \\
\text { accidentally. }\end{array}$ & $\begin{array}{l}\text { Mastruço-de-galinha; } \\
\text { Peppergrass }\end{array}$ & $\begin{array}{c}\text { I.C. Borges } 60, \text { SMDB } \\
18462\end{array}$ \\
\hline Raphanus raphanistrum L. & $\begin{array}{c}\text { Naturalized, } \\
\text { originated in Europe } \\
\text { and introduced as a } \\
\text { forage. }\end{array}$ & $\begin{array}{l}\text { Nabiça; jointed charlock, } \\
\text { jointed radish, jointed wild } \\
\text { radish, sea radish, white } \\
\text { charlock, and wild radish }\end{array}$ & $\begin{array}{c}\text { I.C. Borges 1, SMDB } \\
18278\end{array}$ \\
\hline Rapistrum rugosum (L.) All & $\begin{array}{c}\text { Naturalized, } \\
\text { originated in Europe } \\
\text { and introduced as a } \\
\text { forage. }\end{array}$ & $\begin{array}{l}\text { Rapistro; annual bastard } \\
\text { cabbage, common giant } \\
\text { mustard or turnipweed. }\end{array}$ & $\begin{array}{c}\text { G. Rau, s.n., SMDB } \\
445\end{array}$ \\
\hline
\end{tabular}

The following keys assist in the identification of genera of Brassicaceae and species of the genus Lepidium in Santa Maria.

Chart 1 - Key to identification of Lepidium species in Santa Maria

\begin{tabular}{|c|c|c|}
\hline 1 & Basal leaves not pinatissect, not rosulate & Lepidium virginicum \\
\hline $1^{\prime}$ & Basal leaves pinatissect, rosulate & 2 \\
\hline 2 & $\begin{array}{c}\text { One to several caulinar leaves semi-auriculate or auriculate, pedicels } \\
\text { pubescent on both faces }\end{array}$ & Lepidium aletes \\
\hline $2^{\prime}$ & Caulinar leaves not auriculate, pedicels pubescent only at the adaxial face & Lepidium bonariense \\
\hline
\end{tabular}

Source: Adapted from Boelcke, 1967 
Chart 2 - Key to identification of Brassicaceae genera in Santa Maria

\begin{tabular}{|c|c|c|}
\hline 1 & Fruit silique with length at least three times longer than the width & 2 \\
\hline $1^{\prime}$ & Fruit silicule with length equal or smaller than the triple of the width & 5 \\
\hline 2 & Prostrate herb, fruit linear, compressed & Cardamine \\
\hline $2^{\prime}$ & Upright herb, fruit linear, not compressed, cylindrical & 3 \\
\hline 3 & Fruit moniliform, indehiscent & Raphanus \\
\hline $3^{\prime}$ & Fruit not moniliform, dehiscent & 4 \\
\hline 4 & Fruit rostrate, nectaries not confluent & Brassica \\
\hline $4^{\prime}$ & Fruit not rostrate, nectaries confluent & Sisymbrium \\
\hline 5 & Fruit biarticulated, striated surface & Rapistrum \\
\hline $5^{\prime}$ & Fruit not biarticulated, smooth or reticulate surface & 6 \\
\hline 6 & Fruit obtriangular, more than one seed per locus of the fruit & Capsella \\
\hline $6^{\prime}$ & Fruit orbicular, suborbicular or oval, one seed per locus of the fruit & 7 \\
\hline 7 & Fruit twinned, rough surface & Coronopus \\
\hline $7^{\prime}$ & Fruit not twinned, smooth surface & Lepidium \\
\hline
\end{tabular}

Source: Adapted from Scalon and Souza, 2002

\subsection{Species descriptions, habit, uses and geographic distribution}

\subsubsection{Brassica rapa L.}

Herbs up to $100 \mathrm{~cm}$ high. Basal leaves rosulate and shortly petiolate, lirataepinatisect, margins crenate to dentate, glabrous. Upper leaves sessile, entire, lanceolate with amplexicaul base, glabrous. Flowers with yellow petals, obovate. Fruits are siliques obliquely ascendent, rostrate and pedicelate.

This species is found in Santa Maria on roadsides. It is considered a ruderal and crop-invasive plant which settles quickly in cereal-growing and olericultural areas where it competes for space, light and soil nutrients (MOREIRA; BRAGANÇA, 
2011). Native to southern Europe, it also occurs in South America. It is found in the Northeast, Midwest, Southeast and South regions of Brazil (SCALON; SOUZA, 2002). (Figures 1, 11-A).

\subsubsection{Capsella bursa-pastoris (L.) Medik.}

Herbs up to $40 \mathrm{~cm}$ high. Basal leaves rosulate and petiolate, entire, pinatilobate or pinatisect. Upper leaves sessile, lanceolate and sagittate at the base, pubescence mixed, simple or with stellate trichomes in all leaves. Flowers with white petals, small and obovate. Fruits obtriangular, similar to old bags that shepherds wore, hence the vernacular name of the species.

This species is often seen on ledges and on sidewalks. It is considered to be a UFP. It is native to Europe, and occurs in India, Japan and North America. In Brazil, it occurs in the Midwest, Southeast and South regions (SCALON; SOUZA, 2002). (Figures 2, 11-B).

Figure 1 - Brassica rapa L. A. Habit; B. flower; C. fruit

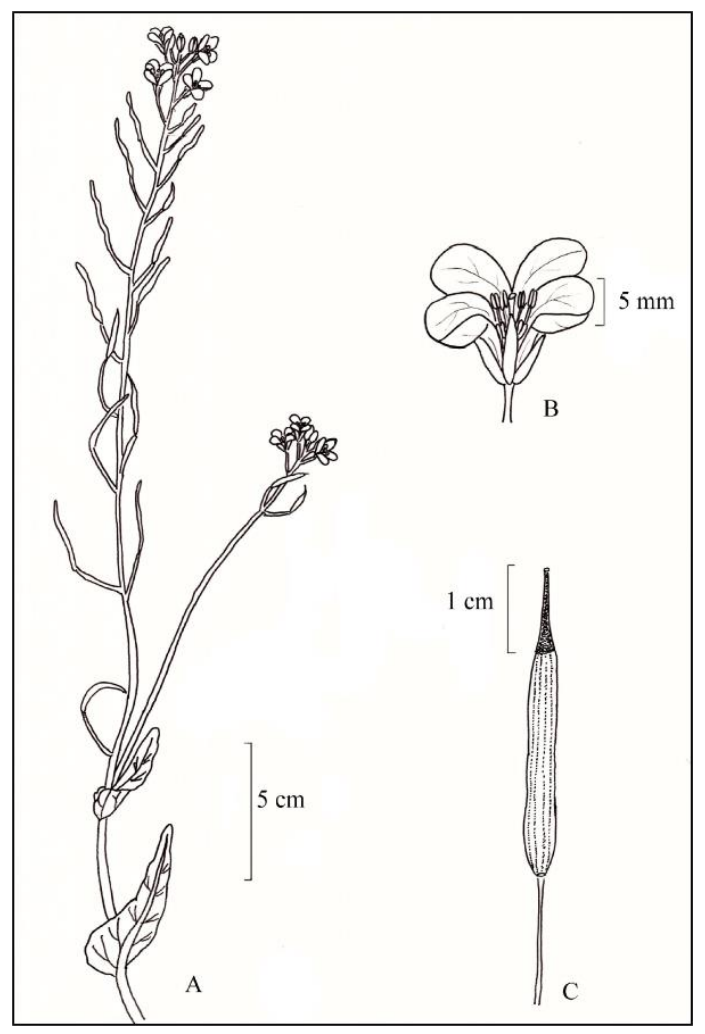


Figure 2 - Capsella bursa-pastoris (L.) Medik. A. Habit; B. flower; C. fruit

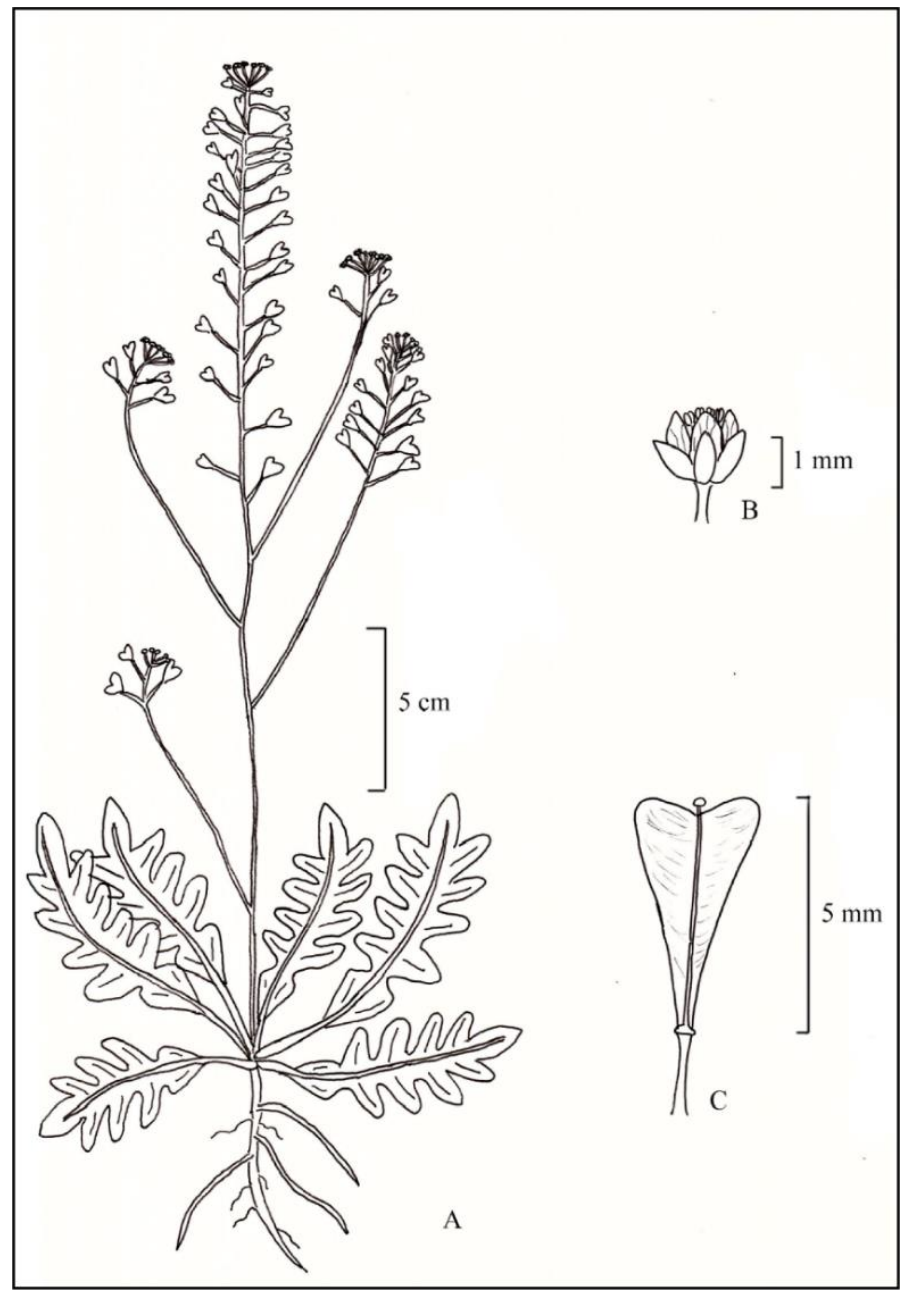

\subsubsection{Cardamine bonariensis Pers.}

Herbs up to $28 \mathrm{~cm}$ high. Basal leaves long-petiolate, not rosulate, margins crenate. Upper leaves petiolate, pinatipartite, blades ovade and margins sinuate to lobate. Flowers with white, violet or yellow petals, unguiculate, with obovate blade, with semicircular lateral nectaries. Fruits are glabrous siliques, Ionger than broad.

Inhabits shaded and humid areas. Occurs extensively in seedling nurseries, gardens and home gardens as an invader. It is native to Central America, occurs in the Midwest, Southeast and South of Brazil (SCALON; SOUZA, 2002). (Figures 3, 11 C). 
Figure 3 - Cardamine bonariensis Pers. A. Habit; B. flower; C. fruit

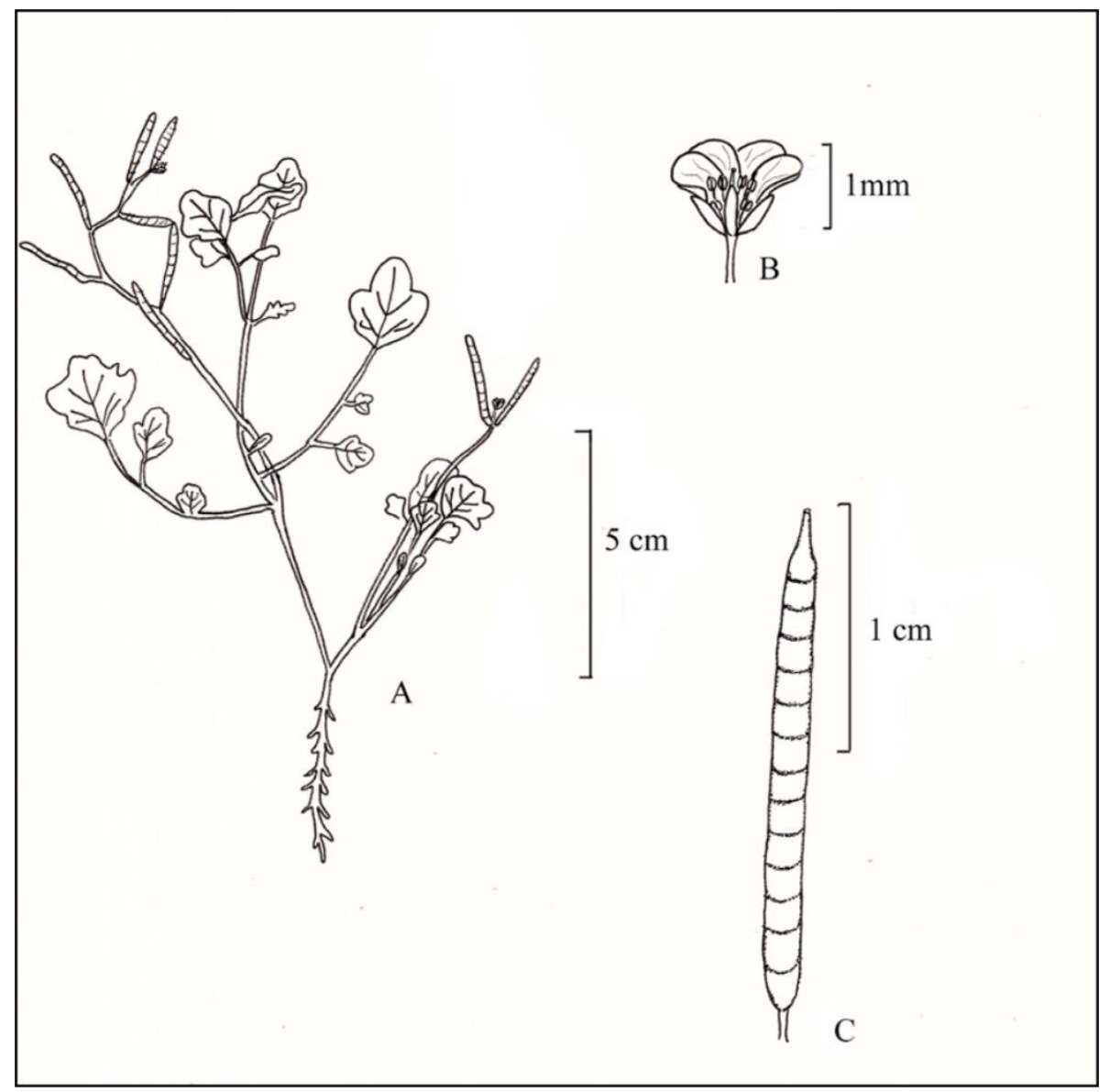

3.1.4 Coronopus didymus (L.) Sm.

Herbs up to $25 \mathrm{~cm}$ high. Basal leaves petiolate, rosulate, pinatisect to bipinatisect, lobes entire or dentate. Upper leaves sessile, blades with 3-9 pinatipartite segments, completely glabrous or with some trichomes at the base of petiole. Flowers are very small, arranged in bunches. Fruits are siliques, consisting of 2 orbicular halves.

It has easily noticeable aroma. It is found in Santa Maria on the sidewalks and fixed to walls. It is considered a UFP and a ruderal and invasive crop plant. It is native to South America, distributed in temperate and subtropical regions. In Brazil, it occurs in the Midwest, Southeast and South regions (Figures 4, 11 -D). 
Figure 4 - Coronopus didymus (L.) Sm. A. Habit; B. flower; C. fruit

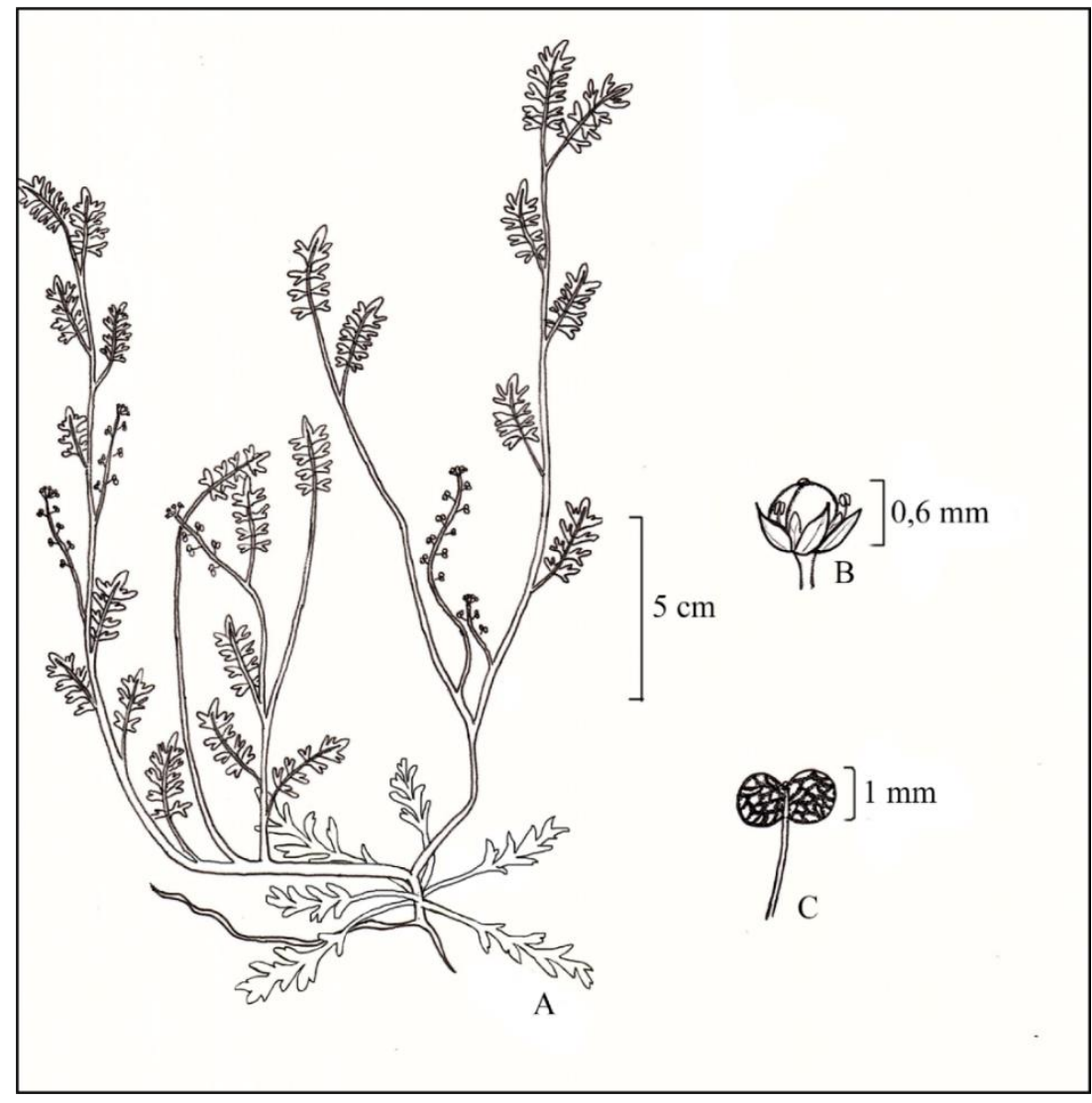

\subsubsection{Lepidium aletes J.F. Macbr.}

Herbs up to $40 \mathrm{~cm}$ high. Basal leaves rosulate, long-petiolate, pinatisect to bipinatisect. Upper leaves reduced, sessile, with wide base and partially auriculate, pinatisect or pinatilobate, sometimes roughly dentate. Flowers with white petals difficult to see with the naked eye because they are very small and sometimes absent. They have a trait that is not common to the family but is common to the genus: androeceious with 2 stamens. Fruits are siliques that can be orbicular to the elliptical with finely crosslinked valves.

In Santa Maria, L. aletes can be found in the urban environment in areas with moist and clay soil. It is native to South America. In Brazil, it occurs only in the South (Flora do Brasil 2020 em construção, 2020). (Figures 5, 12-A). 


\subsubsection{Lepidium bonariense L.}

Herbs up to $50 \mathrm{~cm}$ high, with several branches covered with white pubescence that grow from the base of the plant. Basal leaves petiolate, rosulate, pinatisect, numerous. Upper leaves sessile, pinatilobate or pinatifid. Flowers with white vestigial petals. Fruits are orbicular to elliptical shaped siliques.

Inhabits well-ventilated modified environments. In Santa Maria it is very common to see this species on sidewalks. It is a ruderal and invasive crop plant. Native to South America. In Brazil it occurs in the Northeast, Southeast and South (Flora do Brasil 2020 em construção, 2020). (Figures 6, 12-B).

Figure 5 - Lepidium aletes J.F. Macbr. A. Habit; B. flower; C. fruit

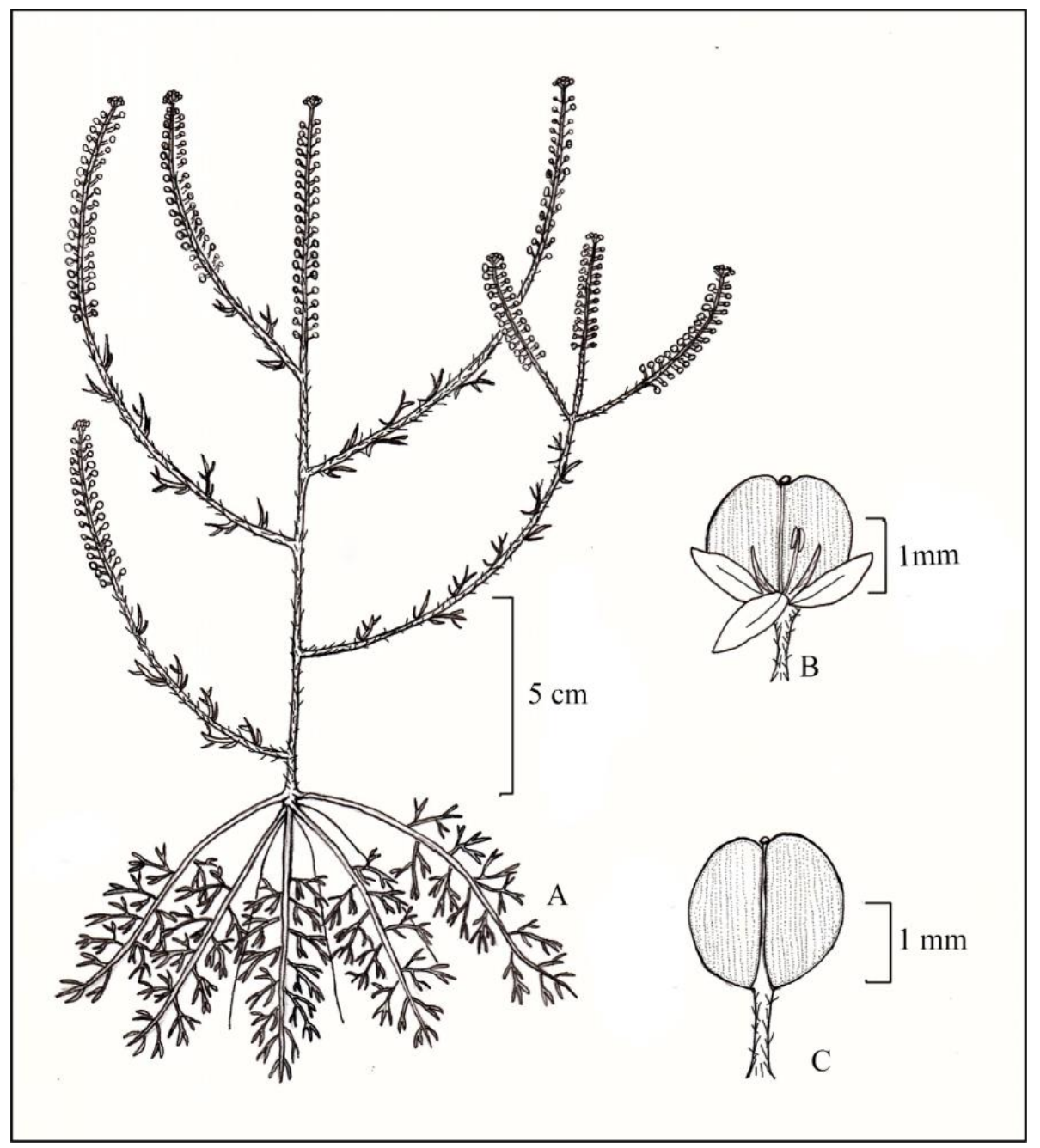


Figure 6 - Lepidium bonariense L. A. Habit; B. flower; C. fruit

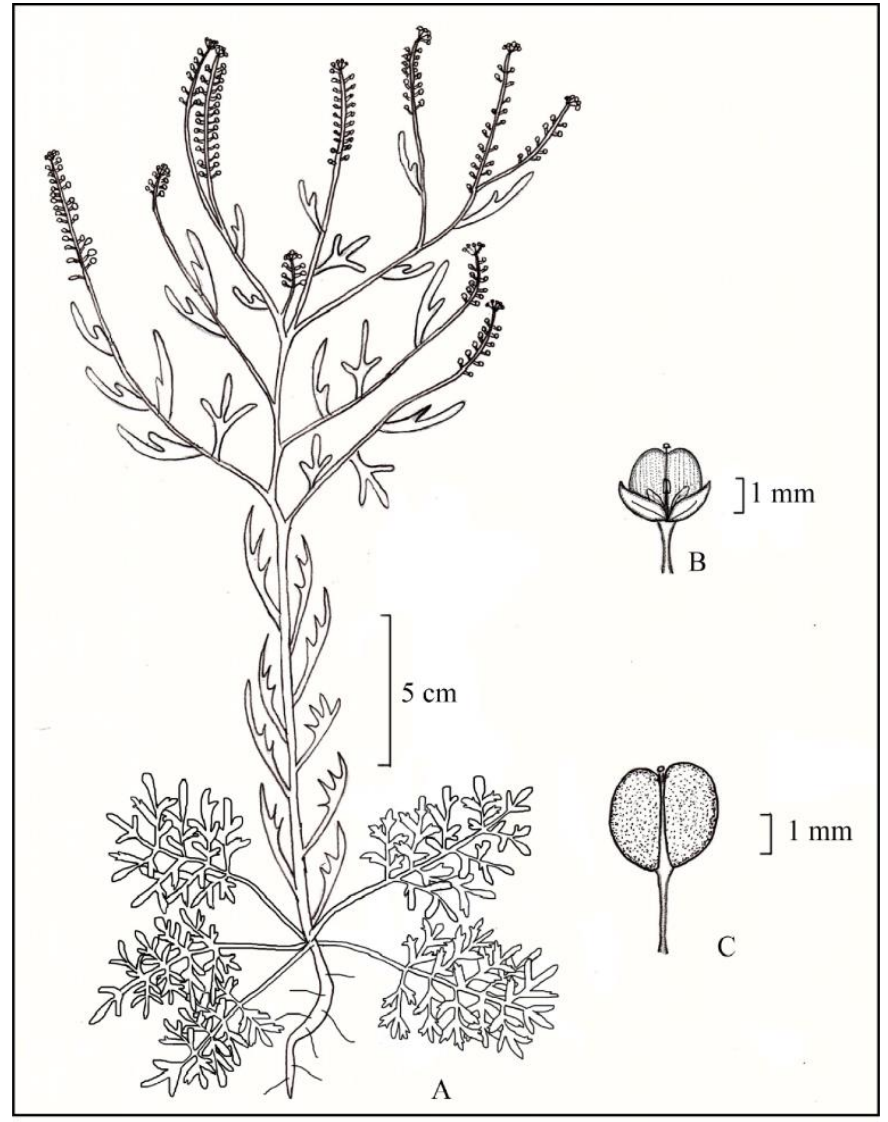

3.1.7 Lepidium virginicum L.

Herbs up to $42 \mathrm{~cm}$ high. Basal leaves shortly petiolate, not rosulate, oblanceolate, serrate, pinatifid to bipinatifid, with short trichomes. Upper leaves sessile, ovate to linear, entire or sharply serrated. Flowers small, with white petals, arranged in racemes. Fruits are round-shaped siliques, which are separated into 2 halves, each containing a seed and always sticking to the stem plant, and at its end the placental system.

The species can be found in Santa Maria on sidewalks. Lives in cultivated humid environments. It is the host of the whitefly, Bemisia tabaci, responsible for the transmission of Begomovirus, and aphids transmitting the PRSV-p virus, responsible for papaya mosaic disease (MOREIRA; BRAGANÇA, 2011). Native to North and Central America, it occurs in the Midwest, Southeast, and South of Brazil (SCALON; SOUZA, 2002). (Figures 7 and 12-C, D). 
Figure 7 - Lepidium virginicum L. A. Habit; B. flower; C. fruit

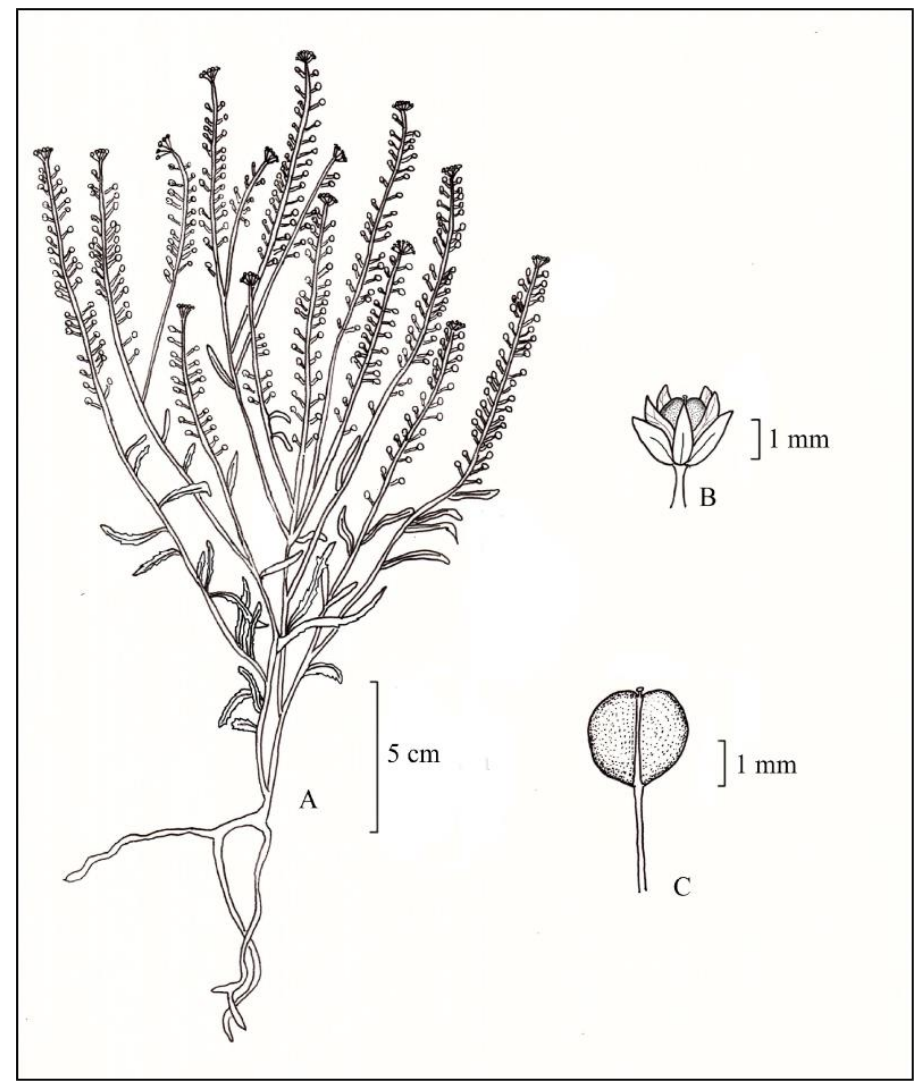

\subsubsection{Raphanus raphanistrum L.}

Herbs up to $80 \mathrm{~cm}$ high. Basal leaves rosulate, petiolate, oblong, obovate or oblanceolate, deeply lirate-pinatifid, occasionally entire, terminal lobe rounded. Upper leaves shortly petiolate, oblong-lirate, margins serrate and terminal leaflet trilobate. Flowers large, with four petals that form a cross. Petals vary greatly in color, from white to violet hues. Fruits are siliques containing numerous seeds separated by constriction.

In Santa Maria it is found in cultivated areas, anthropized environments, wastelands, among other places, where it forms considerable populations. It occurs very often in lettuce, potato and carrot crops and in peach orchards (MOREIRA; BRAGANÇA, 2011). Native to southern Europe, it is distributed in temperate and subtropical regions. In Brazil, it occurs in the Midwest, Southeast and South (SCALON; SOUZA, 2002). (Figures 8, 12-E). 
Figure 8 - Raphanus raphanistrum L. A. Habit; B. flower; C. fruit

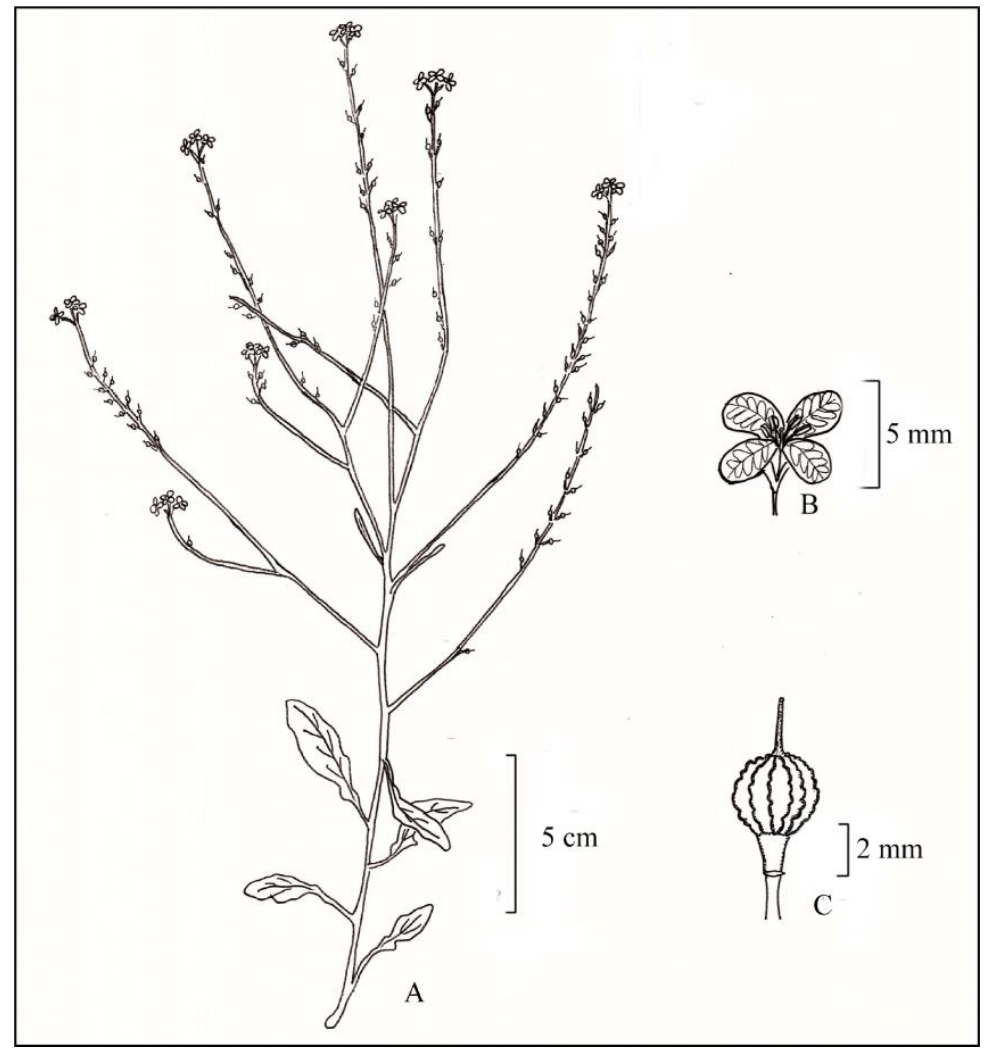

\subsubsection{Rapistrum rugosum (L.) All.}

Herbs up to $60 \mathrm{~cm}$ high. Basal leaves petiolae, lirate-pinatisect with a big terminal lobe and with the surface frequently a little rough and harsh, margins irregularly serrate. Upper leaves petiolate, oblong-lanceolate to lanceolate, margins entire to irregularly serrate. Flowers with yellow petals, rarely white, unguiculate. Fruits siliques, biarticulated, leathery; lower articule cylindrical or bivalve in the terminal part; upper articule persistent, subspherical, broader than inferior, longitudinally striated.

It often grows in cultivated environments, such as home and commercial gardens. (MOREIRA BRAGANÇA, 2011). It is native to Europe, and occurs in Asia Minor, North Africa, North America and South America. In Brazil, it is present in the Midwest, Southeast and South (SCALON; SOUZA, 2002). This species is not very common in Santa Maria, having only one record and therefore was not localized for photographs and new collections. (Figure 9). 
Figure 9 - Rapistrum rugosum (L.) All.. A. Habit; B. flower; C. fruit

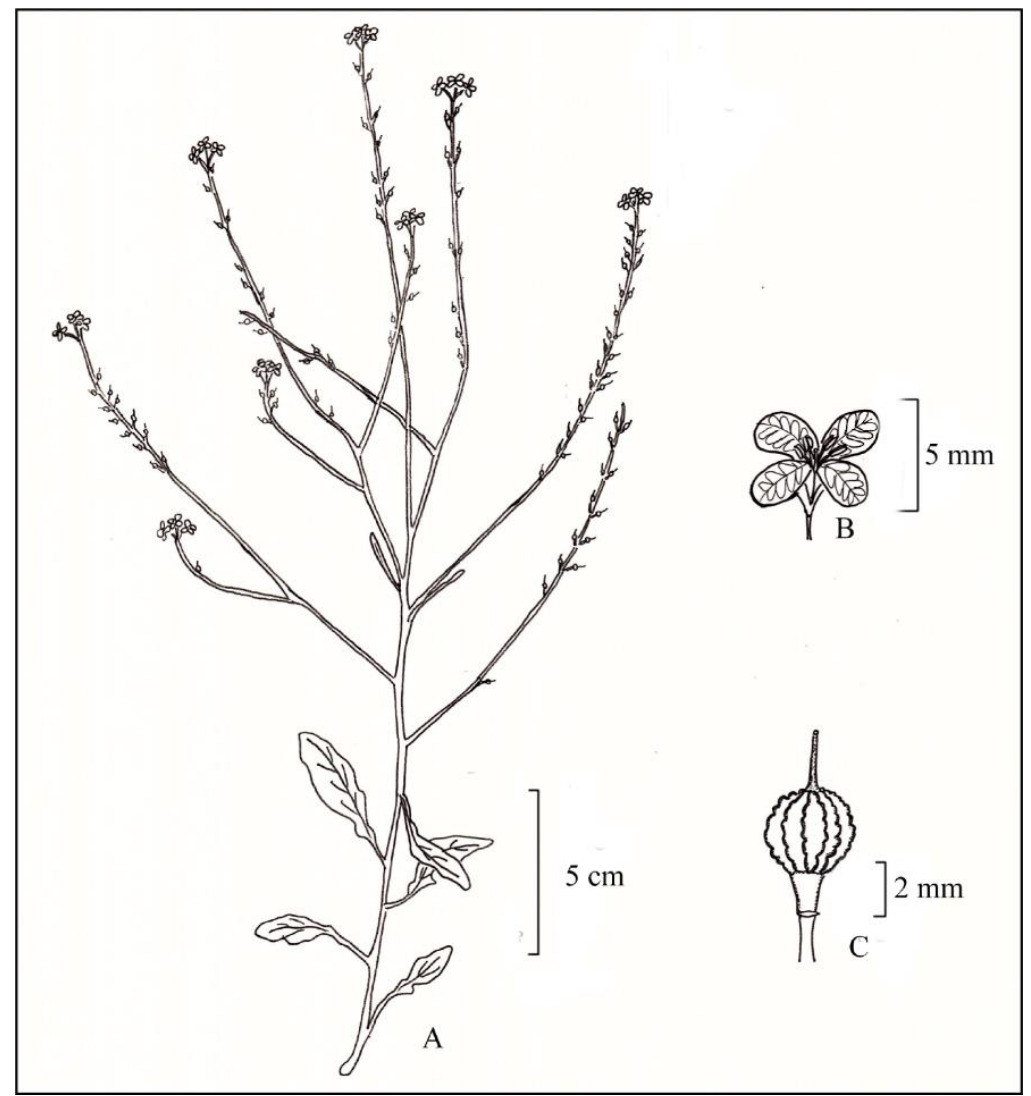

3.1.10 Sisymbrium officinale (L.) Scop.

Herbs up to $130 \mathrm{~cm}$ high. Basal leaves rarely rosulate, petiolate, oblanceolate or oblong-obovate, runcinate-pinatipartite to runcinate liratepinatisect, margins dentate, usually with 3 to 4 lobes each side. Upper leaves shortly petiolate, hastate-lobulate to oblong-hastate with lobes oblong-lanceolate, sometimes linear. Leaves all densely pilose. Flowers small, with yellow petals and narrow, obovate blade. Fruits are round siliques, glabrous pubescent.

This species is found on farmland, vacant land, and on the roadside. It is considered a medicinal plant in some studies (BAHMANI, ZARGARAN RAFIEIANKOPAEI, 2014). It is native to Europe (SCHNEIDER, 2007). In Brazil it occurs in the South and Southeast (Flora do Brasil 2020 em construção, 2020). It is not a very common species in Santa Maria and has been recorded two times and has not been found for photographic records and new collections. (Figure 10). 
Figure 10 - Sisymbrium officinale (L.) Scop. A. Habit; B. flower; C. fruit

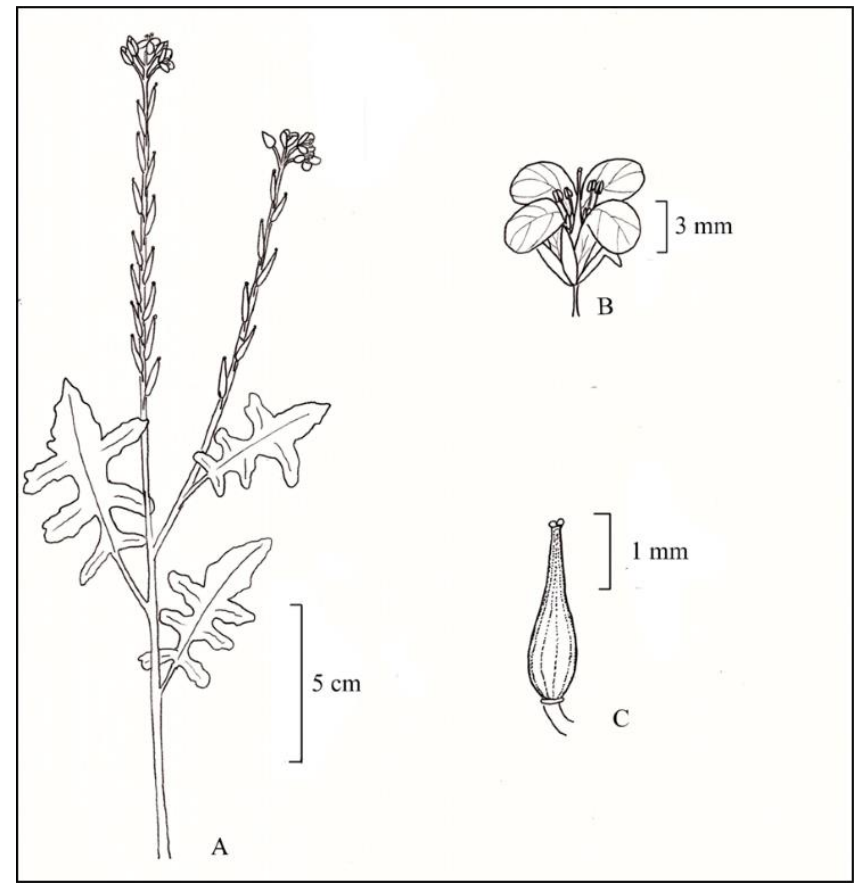

Figure 11 - A. Brassica rapa L.; B. Capsella bursa-pastoris (L.) Medik; C. Cardamine bonariensis Pers.; D. Coronopus didymus (L.) Sm
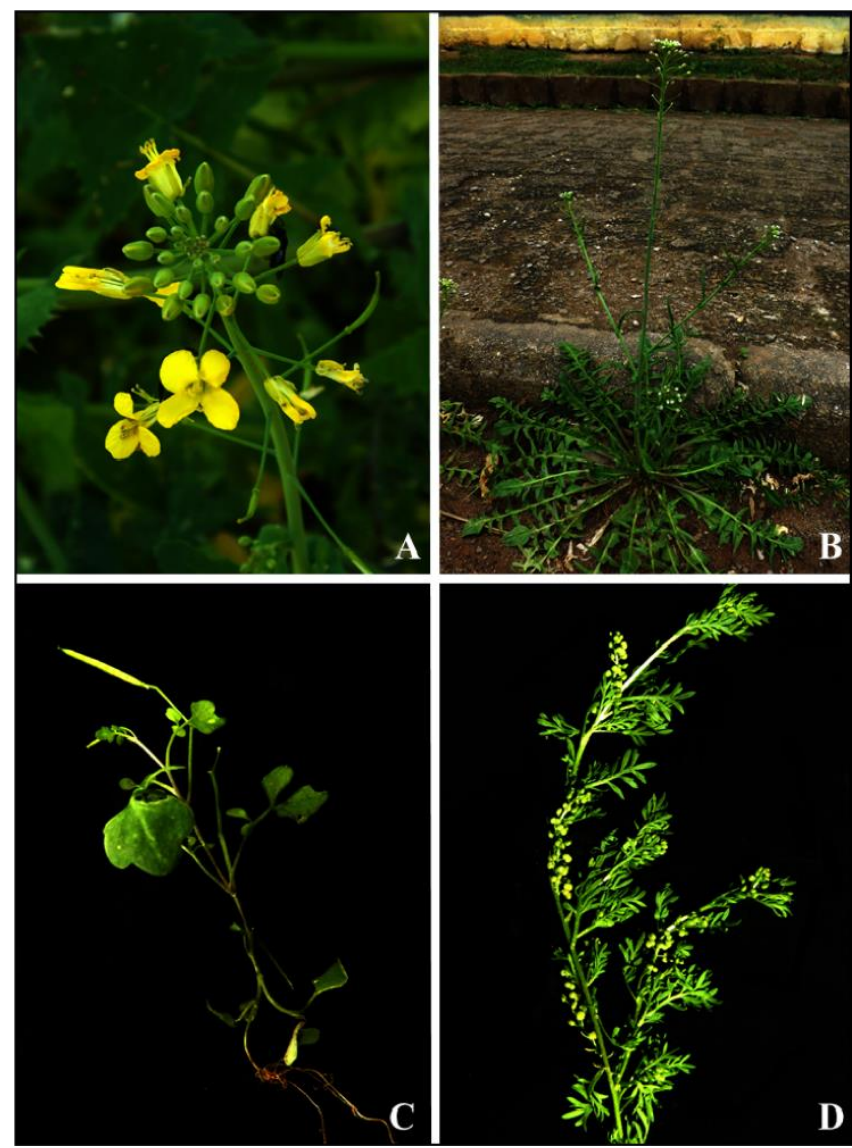

Ci. e Nat., Santa Maria, v.43, e25, 2021 
Figure 12 - A. Lepidium aletes J.F. Macbr.; B. Lepidium bonariense L.; C. Lepidium virginicum L.; D. Detail of flowers and fruits of L. virginicum L.; E. Raphanus raphanistrum L.

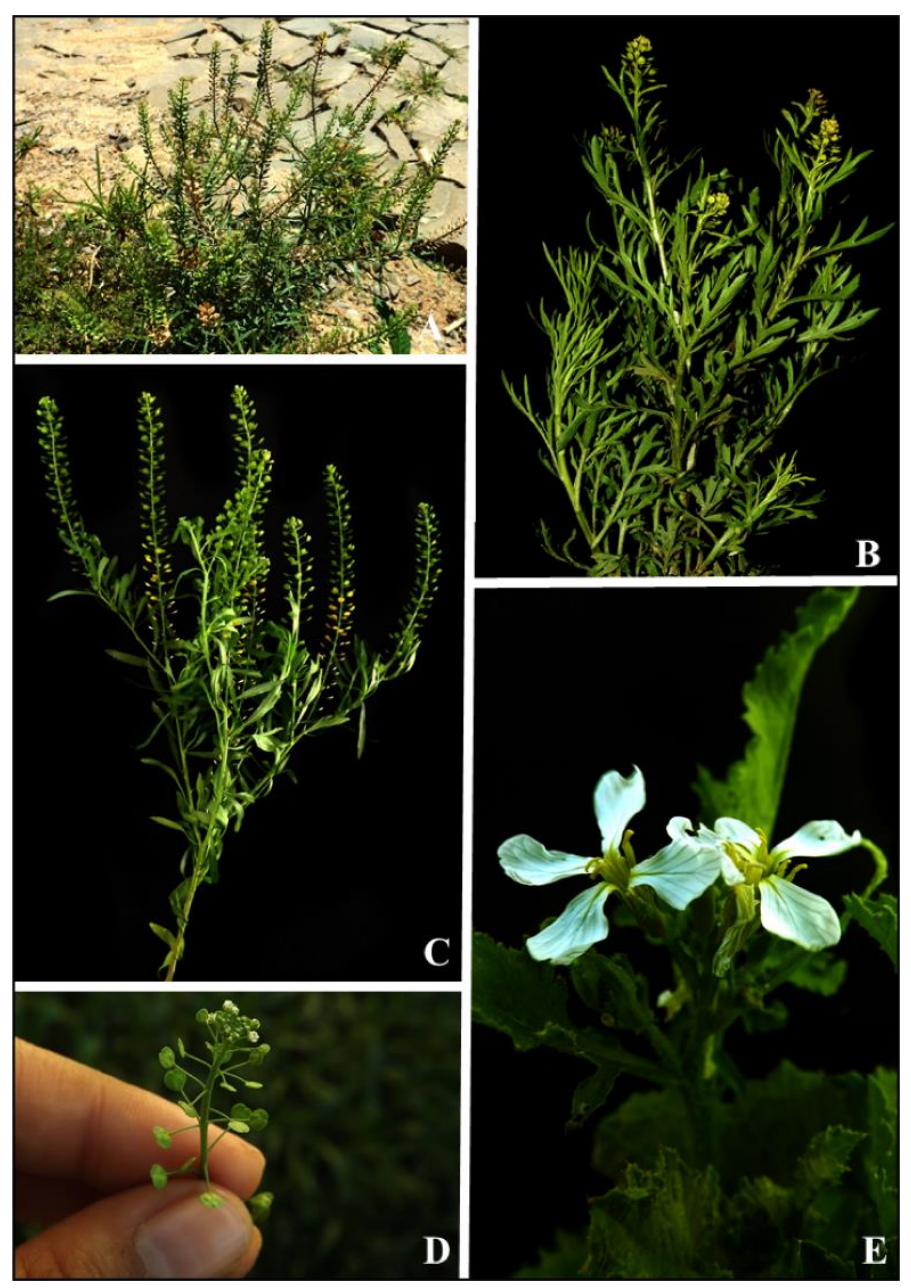

\section{CONCLUSION}

Most of the native and naturalized species from Brassicaceae of Santa Maria can be found in urbanized environments. Of the recorded species, only two were native to Santa Maria: Lepidium aletes, and L. bonariense. There was an increase of three species and one genus in relation to the last survey made for this family with only 7 species and 7 genera (BELTRÃO, 1962; BELTRÃO, 1965). This increase is relevant because it is closer to the number of species found in the state of Rio Grande do Sul overall (20 spp.) and expected to be found in Santa Maria. 


\section{ACKNOWLEDGMENT}

The authors would like to thank SMDB herbarium staff for their support and anonymous reviewers for their valuable suggestions on the manuscript.

\section{REFERENCES}

AL-SHEHBAZ, IA. A generic and tribal synopsis of the Brassicaceae (Cruciferae). Taxon, v. 61, n. 5, p. 931-954, 2012. Available from: https://www.jstor.org/stable/41679341

BAHMANIA, M.; ZARGANB, A.; RAFIEIAN-KOPAEIC, M. Identification of medicinal plants of Urmia for treatment of gastrointestinal disorders. Revista Brasileira de Farmacologia, v. 24, n. 4, p. 468-480, 2014.

BELTRÃO, R. Flórula fanerogâmica do município de Santa Maria, RS, Brasil. Primeiro suplemento. $2^{\mathrm{a}}$ ed. Santa Maria; Boletim do Instituto de Ciências Naturais da Universidade Federal de Santa Maria, 1965.

BELTRÃO, R. Flórula fanerogâmica do município de Santa Maria, RS, Brasil. Santa Maria. $1^{\text {a }}$ ed. Boletim do Instituto de Ciências Naturais da Universidade Federal de Santa Maria, 1962.

BOELCKE, O. Cruciferae. In: SUAREZ, D.A.; BOELCKE, O.; BURKART, A.; CABRERA, A.L.; DAWNSON, G.; FABRIS, H.Á.; GIUSTI, L.; PONTIROLI, A. (Eds.) Flora de la província de Buenos aires. Buenos Aires: Instituto Nacional de Tecnologia Agropecuária, 1967. p. 281-356.

BONA, M. Taxonomic revision of Lepidium L. (Brassicaceae) from Turkey. J. Fac. Pharm. Istanbul, v. 44, n. 1, p. 31-62, 2014.

DAL'ASTA, A.P. Elaboração de Zoneamento Geoambiental para o Perímetro Urbano de Santa Maria - RS. Dissertação (Mestrado em Geografia: Análise Ambiental e Dinâmica Espacial) Centro de Ciências Naturais e Exatas, Universidade Federal de Santa Maria/RS; 2009. 176 p.

FLORA DO BRASIL 2020 EM CONSTRUÇÃO [internet]. Jardim Botânico do Rio de Janeiro. Available from: http://floradobrasil.jbrj.gov.br/.

INSTITUTO BRASILEIRO DE GEOGRAFIA E ESTATÍSTICA [internet]. Santa Maria, 2019. Available from: https://cidades.ibge.gov.br/brasil/rs/santa-maria/panorama.

JUDD, W.S.; CAMPBELL, C.S.; KELLOGG, E.A.; STEVENS, P.F.; DONOGHUE, M.J. Sistemática Vegetal: um enfoque filogenético. 3. ed. Porto Alegre : Artmed, 2009.

KOCH, M.A.; GERMAN, D.A.; KIEFER, M.; FRANZKE, A. Database Taxonomics as Key to Modern Plant Biology. Trends in plant Science, v. 23, n. 1, p. 4-6, 2018. 
LONGHI, S.J.; ARAÚJO, M.M.; KELLING, M.B.; HOPPE, M.J.; MULLER, I.; BORSOI, G.A. Aspectos fitossociológicos de fragmento de floresta estacional decidual, Santa Maria, RS. Ciência Florestal, v. 10, n. 2, p. $59-74,2000$.

LYSAK, M.; KOCH, M.A. Phylogeny, Genome, and Karyotype Evolution of Crucifers (Brassicaceae). In: SCHMIDT, R.; BANCROFT, I. (eds.). Genetics and genomics of the Brassicaceae. Springer, 2010; $1-31$.

MOREIRA, H.J.C; BRAGANÇA, H.B.N. Manual de plantas infestantes: Brassicaceae. São Paulo: Agricultural products, 2011.

PEREIRA, P.R.B.; NETTO, L.R.G.; BORIN, C.J.A.; SARTORI, M.G.B. Contribuição à geografia física do município de Santa Maria: unidades de paisagem. Geografia - Ensino \& Pesquisa, v. 3, p. 37-68, 1989. Available from: http://dx.doi.org/10.5902/2236499423884

PRINA, A.O. Las crucíferas de la província de la Pampa, República Argentina. Rev. Fac. Agronomia - UNLPam, v. 8, n. 2, p. 29-67, 1995.

SCALON, V.R.; SOUZA, V.C. Brassicaceae. In: WANDERLEY, M.G.L.; SHEPERD, G.J.; GIULIETTI, A.M. (eds.). Flora fanerogâmica do estado de São Paulo. São Paulo: Hucitek, 2002. p. 57-63.

SCHNEIDER, A. A. A flora naturalizada do Rio Grande do Sul, Brasil: Herbáceas subespontâneas. Biociências (on-line), v. 15, n. 2, p. 257-268, 2007.

SOUZA, V.C.; LORENZI, H. Botânica sistemática: guia ilustrado para identificação das famílias de Angiospermas da flora brasileira, baseado em APG IV. $4^{\text {a }}$ ed. Nova Odessa: Jardim Botânico Plantarum, 2019.

SPECIES LINK [internet]. 2019. Available from: http://www.splink.org.br/.

THIERS B. (continuously updated) Index Herbariorum: A Global Directory of Public Herbaria and Associated Staff. New York Botanical Garden's Virtual Herbarium. Available from: http://sweetgum.nybg.org/science/ih/

TROPICOS [internet]. 2019. Available from: https://www.tropicos.org/. 


\section{Authorship Contribution}

\section{1 - Isabel Costa Borges}

Pós-graduanda em Educação Ambiental

Isabelcostaborges.ib@gmail.com - https://orcid.org/0000-0002-8020-4382

Contribuition: Conceptualization, Data curation, Investigation, Visualisatio, Writing original draft, Writing - review and editing

\section{2 - Liliana Essi}

Docente do Programa de Pós-Graduação em Agrobiologia

liliana.essi@ufsm.br - http://orcid.org/0000-0001-5548-6448

Contribuition: Conceptualization, Writing - review and editing, Project administration

\section{How to quote this article}

BORGES, I. C.; ESSI, L. Brassicaceae Burnett in the municipality of Santa Maria, Rio Grande do Sul, Brazil. Ciência e Natura, Santa Maria, v. 43, e25, p. 1-21, 2021. DOI 10.5902/2179460X39828. Available from: https://doi.org/10.5902/2179460X39828. Accessed: Month Abbreviated. day, year. 